\title{
THE COVERAGE OF THE FAIR LABOR STANDARDS ACT AND OTHER PROBLEMS IN ITS INTERPRETATION
}

\author{
Frank E. CoOprR*
}

Broad responsibilities of statutory interpretation and administrative interpolation are imposed on the Wage and Hour Division of the Department of Labor in determining the coverage of the Fair Labor Standards Act of 1938. Two principal factors (interesting in themselves as examples of legislative technique) contribute to this end: first, use of elastic, vague, and broadly inclusive language in the provisions affirmatively establishing the coverage; second, delegation to an Administrator of the power to define the meaning of certain generic terms employed in those sections of the Act which establish exclusions and exemptions.

The result has been chiefly to generate doubts and uncertainty. But some cold comfort can be derived from the circumstance that at least one question as to the coverage of the Act can be answered with certainty. When an employer inquires whether the wage and hour requirements of the law apply to his business, an attorney can with comparative safety always answer in the negative. The fundamental inquiry in the determination of the coverage of the Act is not the nature of the employer's business, but the nature of the job of each employee. Many employers find that some of their employees are within the Act, while others are excluded. ${ }^{1}$ If an employee is engaged in interstate commerce, or in a job which is necessary to the production ${ }^{2}$ of goods for interstate commerce, he is entitled to the benefits of the Act, unless he falls within one of the exempted classes, ${ }^{3}$ or unless his employer cannot constitutionally be compelled to grant him such benefits. ${ }^{4}$

In this article, an examination will be made of the content of the two phrases "engaged in commerce" and "engaged in the production [or in a process necessary to the production] of goods for commerce." A brief analysis of the several partial and

- A.B., I931, J. D., 1934, University of Michigan. Member of the Detroit, Michigan, bar, associated with Beatumont, Smith \& Harris. Contributor to legal periodicals.

${ }^{2}$ Why Congress in the enactment of this Act thus. changed the usual test is a matter of considerable speculative interest. It seems likely, however, that the chief purpose was to avoid certain problems relative to the constitutional validity of the Act, and all such questions are excluded from the scope of this article.

3 The Act employs primarily the phrase "engaged in production," but the Act further provides that an employee is deemed to be engaged in the production of goods if he is engaged in any process necessary to the production thereof.

3 These are discussed in some detail, infra, pp. 343-350.

- Constitutional issues are discussed in a separate article in this symposium. For other discussions, see (1939) 52 Harv. L. Rev. 645; Cooper, "Extra Time for Overtime" Now Law (1938) 37 Mrch. L. Rev. 28. 
total exemptions will be undertaken; and reference will be had, finally, to certain practical problems centering around the terms "wage"5 and "regular rate of pay" in connection with the substantive requirement of the Act that covered employees be paid, for overtime work, at a rate not less than one and one-half times the regular rate of pay at which they are employed. ${ }^{7}$ While any complete investigation of these problems necessarily would involve consideration of certain of the constitutional issues raised by the Act, these questions will not be here considered.

Broad though the powers of the Administrator are in determining the coverage, they are not so complete as was provided in some of the early drafts of the wage and hour bill, ${ }^{8}$ under which the Administrator would have been empowered, first, to make investigations to determine which industries were so closely related to the flow of interstate commerce as to be subject to federal control and, secondly, to decide what the minimum wage and maximum hour requirements should be as to particular industries. Congress saw fit to reduce the scope of administrative freedom by limitations at once important and indefinite; and because of this, the implementation of the Act by the Administrator affords many interesting examples of the workings of the administrative process in filling in the interstices of a rather loosely knit legislative fabric.

Where power is delegated to the Administrator to make regulations (as in the section authorizing employment at substandard wages of learners, apprentices, messengers, and handicapped workers under certificates, ${ }^{0}$ and in the section requiring the Administrator to define certain exempted classes ${ }^{10}$ ), he has published detailed rules closely conforming in style to legislative enactments. Where such power is not delegated, however, the Administrator has drawn on a variety of sources as a means of publicizing and seeking popular acceptance of his interpretation of ambiguous or obscure provisions of the Act. ${ }^{11}$ A number of Interpretative Bulletins have been issued, drafted on the whole in persuasive rather than decretal language, interpreting sections of the Act which the Administrator does not have power to particularize through the medium of regulations. ${ }^{12}$ Information dealing with less controversial questions as to coverage is disseminated through the medium of published Questions and Answers, designed to enable employers unskilled in reading legislative language to appreciate by example the meaning of many of the provisions of the Act and of regulations issued thereunder relating to coverage. ${ }^{13}$ Finally, in opinions of counsel

${ }^{5} \$_{3}(\mathrm{~m})$. $\quad{ }^{6} \S_{7}(\mathrm{a})$.

${ }^{8}$ See Forsythe, Legislative History of the Fair Labor Standards Act, infra, p. 464.

- \$r4.

${ }^{21}$ One of the features of the administration of the law has been the commendable effort to elicit popular co-operation.

${ }_{23}$ It should be noted that the Administrator has carefully pointed out, in published releases, that he has not been empowered to pass on the questions so discussed; and that the final answers are for the courts. The bulletins state what interpretation will be followed by the administrative officers unless the courts impose on them a different rule of practice or unless on reconsideration the administrative ruling is changed.

${ }_{18}$ These releases have been accompanied by the warning that each answer has been made on the basis of the particular circumstances involved, and that the answers should not be construed as covering cases that might be regarded as similar. 
and public addresses, the administrative officials have sought to create a widespread acceptance of the liberal interpretation of the Act favored by the Administrator. References to illustrative instances of the employment of these techniques will be made hereinafter. They possess a distinct advantage in that, because of their semiofficial nature, they can be used to suggest interpretations which, if issued in the form of regulations, might be invalid as going beyond the statute under which they were promulgated. ${ }^{14}$

\section{Employees Engaged In Interstate Commerce}

Uncertainty as to the implications of recent Supreme Court decisions ${ }^{15}$ renders doubtful predictions as to the comprehensiveness of the apparently simple phrase including within the provisions of the Act employees "engaged in commerce."16 Certainly included are workers engaged in the operation of the instrumentalities of interstate commerce. The typical case would be members of a train crew, or wireless operators. ${ }^{17}$ But what is to be said of the "back shop" employees-those who do not come into direct contact with the actual movement of commerce? A ready analogy is found in decisions construing the provisions of the Federal Employers' Liability Act, ${ }^{18}$ under which only those employees who were engaged in interstate transportation were deemed to be included within similar language. ${ }^{19}$ If the phrase "engaged in commerce" be again construed to mean "engaged in transportation," the problem would be greatly simplified; but since the decisions setting up this definition appear to be founded in part at least on doubts as to the constitutionality of including within the Federal Employers' Liability Act employees who were not engaged in transportation, and since later decisions go some distance toward erasing these doubts, ${ }^{20}$ it may well be argued that in passing upon the Fair Labor Standards Act the courts will feel free to ignore this restrictive interpretation and hold that employees whose work is essential to the smooth operation of instrumentalities of commerce are themselves engaged in commerce, even though their contact with interstate movement of commodities or intelligence is only indirect. Conceding jural freedom to broaden the concept of the phrase "engaged in commerce," however, can it not properly be argued that Congress, in choosing to re-employ language which had been judicially con-

\footnotetext{
14 For cases invalidating regulations of administrative agencies on this ground, see: Campbell v. Long \& Co., 28 I U. S. 610 (1930); Morrill v. Jones, I06 U. S. 466 (I882); United States v. Symonds, 120 U. S. 46 (1887); United States v. Eaton, 144 U. S. 677 (1892); United States v. United Verde Copper Co., I96 U. S. 207 (Ig05); United States v. George, 228 U. S. I4 (1913).

${ }_{16}$ Particularly Mulford v. Smith, 59 Sup. Ct. 648 (I939); Consolidated Edison Co. v. National Labor Relations Board, 305 U. S. I97 (I938); Santa Cruz Packing Co. v. National Labor Relations Board, 303 U. S. 453 (1938); National Labor Relations Board v. Jones \& Laughlin Steel Corp., 30I U. S. I (1937). $10 \$ \$ 6(\mathrm{a}), 7(\mathrm{a})$.

${ }^{17}$ Many such employees are exempted from the hours provisions by $\$ 1_{3}(\mathrm{~b})$, referring to (a) any employee with respect to whom the Interstate Commerce Commission has power to establish qualifications and maximum hours of service pursuant to the provisions of $\$ 204$ of the Motor Carrier Act, (b) any employee of an employer subject to the provisions of Part $I$ of the Interstate Commerce Act.

18 STAT. 65 (1908), 45 U. S. C. \$5I (1934).

10 Shanks v. Delaware, L. \& W. R. R., 239 U. S. 556 (19r6); New York, N. H. \& H. R. R. v. Bezue, 284 U. S. 415 (1932).

${ }^{20}$ See cases cited in (1939) 52 Harv. L. Rev. 646, at 651, 652.
} 
strued, must be held to have intended adoption of such construction? If Congress intended to include employees who would be excluded by defining "engaged in commerce" as "engaged in transportation," why did not the draftsmen provide that the Act should apply to all employees whose work "directly or substantially affects" commerce? ${ }^{21}$

Quite properly, all of these doubts have been resolved by the Administrator's general counsel in favor of a broad interpretation of the Act. As was stated in an early Interpretative Bulletin: ${ }^{22}$

"The first category of workers included,-those 'engaged in (interstate) commerce,' applies, typically but not exclusively, to employees in the telephone, telegraph, radio and transportation industries since these industries serve as the actual instrumentalities and channels of interstate commerce. Employees who are an essential part of the stream of interstate commerce are also included in the phrase 'engaged in commerce'; for exampleemployees of a warehouse whose storage facilities are used in the interstate distribution of goods."

The reference above made to the "stream-of-commerce" cases as authority for the inclusion of employees not directly engaged in interstate commerce is illustrative of the facility with which those charged with the administrative interpretation of the Act find support for broad interpretation thereof in somewhat unexpected sources. Similarly, the general counsel has suggested ${ }^{23}$ that since a corporation is held not to be doing business within a state (so as to subject itself to the statutory penalties applicable to unlicensed foreign corporations) by installing in a factory therein mechanical equipment sold in an interstate transaction, it should follow that employees engaged in such installation are engaged in commerce, and not in a local activity. Since the decisions in question ${ }^{24}$ are commonly referred to as being based on the theory that a state may not prohibit a local activity which is intimately associated with an interstate transaction, the opinion referred to may fairly be characterized as an interpretation that a worker engaged in local activity intimately associated with interstate commerce is ipso facto engaged in interstate commerce. A more comprehensive interpretation of the phrase could scarcely be desired by the most ardent champions of work-sharing. ${ }^{25}$ On the other hand, the Administrator recognizes the dangers inherent in a ruthlessly logical application of a rule thus formulated, and concedes that employees whose direct contact with the actual movement of commerce is slight should perhaps be excluded from the operative effect of the Act for purely practical reasons. ${ }^{26}$

${ }^{21}$ It is on this theory that the federal power has been held to extend to at least some aspects of the activities of these "back shop" employees. Virginian Ry. v. System Federation No. 40, 300 U. S. 515 (1937).

${ }_{22}$ Wage \& Hour Div., Interpr. Bull. No. r, Oct. 12, 1938, I WAge \& Hour Reg. MaN. (1939) 72.

${ }^{2 s}$ Letter opinion, published in mimeographed form through the Wage and Hour Division's mailing list. (I939) 2 WAGE \& Hour REP. II; id. at 72.

${ }^{24}$ E.g., York Mfg. Co. v. Colley, 247 U. S. 21 (1918).

${ }^{25}$ It would seem that the effect of the Act is as much to encourage the sharing of work as to require payment of wages conformable to a desirable standard of living. See Cooper. supra note 4, at $3 \mathbf{I}$.

${ }^{20}$ In a mimeographed release, No. R-207, Feb. 28, 1939, published as a commentary on Interpretative Bulletins Nos. 5 and 6, it is stated: "This Division has not expressed any opinion as to whether any or all 
It seems reasonably predictable that administrative interpretation will include within the category of employees "engaged in commerce" all those whose connection with interstate activities is sufficiently intimate that Congressional regulation of their employment can be validated under the doctrine that the federal power extends to local activities directly or substantially affecting commerce. It is not unlikely that this view may ultimately be judicially accepted. ${ }^{27}$ Coverage will probably extend not only to those actually employed in interstate transportation or communication, but to extra-state purchasing agents, ${ }^{28}$ to employees engaged in the actual unloading of goods received from other states, ${ }^{29}$ at least where the continuity of shipment has not been broken by prolonged delay, ${ }^{30}$ and possibly to other employees whose activities are closely connected with interstate transactions.

\section{Employees Engaged In the Production of Goods for Commerce}

Most employees entitled to the benefits of the Act can claim rights thereunder because of their inclusion in the class of those "engaged in the production of goods for commerce." Consideration of the coverage of this clause can conveniently be divided into two inquiries: first, what employees are "engaged in production"; second, how is it to be determined whether the goods produced are "goods for commerce"?

\section{A. Employees Engaged in Production}

Suppose a candy manufacturing concern maintains a company car and employs a chauffeur who is paid thirty-five dollars a week and who is required to be on duty from eight until six o'clock five days a week to drive company officials on business calls. Is he engaged in the production of candy (and entitled to extra pay because he is on duty more than 44 hours a week)? The Wage and Hour Division would say "yes." 31 Whether this interpretation of the Act is correct involves one of the most important and difficult problems of statutory construction arising in connection with the Wage and Hour Law.

The difficulty arises by reason of the statutory definition of the word "produced," which is declared to mean" "produced, manufactured, mined, handled, or in any other manner worked on in any State" [note that each suggested synonym requires physical contact between employee and the article of manufacture] "and for the purposes of this Act an employee shall be deemed to have been engaged in the production of goods if such employee was employed in producing, manufacturing, mining, handling, transporting, or in any other manner working on such goods, or in any process or occupation necessary to the production thereof, ..."

\footnotetext{
of the employees of small telephone exchanges, which transmit interstate long distance calls very infrequently, are engaged in commerce." In Bulletins 5 and 6 , the suggestions as to the meaning of this phrase were so broad as to imply that coverage of all switch board operators was assumed.

${ }^{37}$ See discussion, (1939) 52 HARv. L. Rev. 645, at 653 .

${ }^{\text {as }}$ Krueger v. Acme Fruit Co., 75 F. (2d) 67 (C. C. A. 5th, 1935).

${ }^{30}$ Puget Sound Stevedoring Co. v. State Tax Commission, 302 U. S. 90 (1939).

${ }^{30}$ Lehigh Valley R. R. v. Barlow, 244 U. S. I83 (19I7).

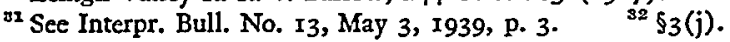


Were it not for the last phrase, italicized by the writer, the provisions of the Act would be applicable only to those workers actually handling the goods. The availability of this phrase, however, has enabled the Wage and Hours Division to take the position that substantially all employees of a plant which manufactures goods are themselves engaged in the production thereof. In an early Interpretative Bulletin, ${ }^{33}$ it was declared, after quoting Section $3(j)$ of the Act:

"Therefore, the benefits of the statute are extended to such employees as maintenance workers, watchmen, clerks, stenographers, messengers, all of whom must be considered as engaged in processes or occupations 'necessary to the production' of the goods. Enterprises cannot operate without employees of these kinds. If they were not doing work 'necessary to the production' of the goods they would not be on the payroll."

The correctness of this interpretation of the law is open to serious doubts. Conceding that "enterprises cannot operate without employees of these kinds," does it follow that production could not proceed without such employees? It would seem not; and if it be true that production could proceed unimpaired even though the jobs of a company chauffeur (or, say, a clerk mailing out advertising matter) were eliminated, how can it be said that the chauffeur or the clerk are engaged in processes necessary to the production of the goods? The theory that all employees are doing work necessary to production because the enterprise could not be successfully operated without them contains elements of non sequitur.

More substantial objections can be raised to the propriety of this administrative interpretation of the Act. Since the statutory definition of "produced" requires physical contact with goods, and since the statutory description of "employees engaged in production" is stated subordinately to the definition of "produced," it can properly be suggested that the definition of "produced" is controlling, and that the significance of subsequent clauses in the same sentence ${ }^{34}$ should be determined with reference to the introductory words. The second phrase of Section $3(j)$ should not be construed to enlarge the first; it is difficult to consider an employee to be "engaged in production" under this section unless his work is "production" as therein defined.

The inclusion within the phrase "engaged in production" of all employees engaged in an occupation necessary to production should be considered also with reference to court decisions apparently recognizing the distinction here suggested between processes necessary to the operation of an enterprise and those necessary to production. $^{35}$

If the draftsmen of the Conference Committee intended, by shifting the criterion from the nature of the employer's business to the character of the work performed by an individual employee, ${ }^{36}$ to find a new and broader basis for justifying federal

${ }^{33}$ Interpr. Bull. No. 1, Oct. 12, 1938, I WAGE \& Hour ReF. MAN. (1939) 72.

${ }^{34}$ The definition of "engaged in production" appears in Section $3(j)$ is a posterior conjunctive clause in the sentence defining "produced."

${ }^{35}$ Maryland Casualty Co. v. W. C. Robertson Co., 194 S. W. Ir40 (Tex. Civ. App. 1917); Ncw Amsterdam Casualty Co. v. State Industrial Commission, 80 Okl. 7, I93 Pac. 974 (r920); Thurman v. Swisshelm, 36 F (2d) 350 (C. C. A. 7th, 1929); McMullin v. Bodine, 247 Pa. 151, 93 Atl. 321 (1915).

${ }^{36}$ Other statutes, of course, are based on the theory of the power of Congress to regulate employers whose enterprises substantially affect commerce. The words "production of goods for commerce" were 
regulation of local activities, ${ }^{37}$ it may be that an interpretation which in effect reverts to the nature of the employer's business will cut out from under the Act its supporting constitutional props.

It is also worth noting that somewhat similar language in the Walsh-Healey Act, which provides wage and hours standards as to employees of employers engaged in the performance of government contracts, has been contrarily interpreted by another Division of the Department of Labor, under which the Fair Labor Standards Act is administered. ${ }^{\mathbf{3 8}}$

The importance of the problem is seen best by brief reference to its practical implications. Letters of inquiry and protest addressed to the Wage and Hours Division attest eloquently to the difficulty of paying time and a half for overtime to office workers employed on a weekly salary, ${ }^{39}$ to watchmen, ${ }^{40}$ and to other classes of non-productive workers paid a weekly salary for, say, a work-week of 45 hours. ${ }^{41}$ So great, indeed, are the practical difficulties which have resulted from the Division's first sweeping pronouncement, that the matter is apparently being reconsidered by the Division, and some recession from its original position is not to be unexpected. ${ }^{\mathbf{2}}$

While considerations of administrative convenience, ${ }^{43}$ as well as the desire to at-

substituted in the Conference Report for the words "affecting commerce," which were used in the House amendment. 83 CoNG. REc. 9246 ( 5938 ).

${ }^{37}$ It may be argued, for example, that the productive effort of any single worker has substantially the same effect on the flow of commerce regardless of the size of the plant in which he is employed, and that therefore minimum wages can be required for the benefit of a worker in a small plant doing chiefly an intra-state business, even though his employer's business, as such, is not subject to Congressional control. See Cooper, supra note 4 , at 40 , note 47.

${ }^{38}$ See Art. 102, Regulations Issued Pursuant to the Walsh-Healey Act. C. C. H. Lab. Law Serv. Tif30r.12, 7305.051. Comparable are the regulations issued under sales tax laws in various states defining the meaning of an excmption in favor of sales for consumption or use in industrial processing. The Michigan regulations, for example, provide (p. 8): "Manufacturing, producing, and processing are divided into three parts: 'administration,' 'production,' and 'distribution.' 'Administration' includes all administrative work such as general office work, all work relating to the administration of the business as a whole, and all work that is performed prior to the time of the commencement of the actual mechanical operations on the article to be manufactured, produced, or processed. 'Production' includes all operations performed in the actual process of producing the manufactured article. 'Distribution' includes all operations subsequent to production."

${ }^{30}$ These problems are discussed in some detail, infra, pp. 350-352.

${ }^{10}$ Who are customarily on duty a large number of hours per week, and whose wages, if increased pursuant to the over-time provisions of the law, would be disproportionately raised.

'I So far as the writer has been able to discover from counselling members of the Michigan Manufacturers Association and from personal inquiry, little difficulty is met in paying productive workers time and a half for overtime-many plants have long operated on this basis; and in all sections of the country, the majority of productive workers receive wages above the statutory minimum. See Cooper, supra note 4 , at $54-56$.

2 In a recent letter, distributed in mimeographed form, March 6, 1939, the Division stated: "We are not, at present, able to render an opinion on this question [whether a watchman, working at an operating plant but employed and paid by an insurance concern or watching service company] of coverage of the Act. This and related questions are under serious consideration. .... In Interpretative Bulletin No. I, p. 4 ... we state our opinion to be that a watchman is engaged in the processes or occupations 'necessary to the production of goods' and is, therefore, covered by the Act. This statement may be qualified by our answer to your question above."

${ }^{4}$ If only employees performing work necessary to prevent stoppage of the actual productive processes are covered, the difficulty of drawing a line is seen by attempting to decide which of the following jobs are included, and which are excluded: stenographers, clerks in office, clerks in factory, inspectors who do 
tain the broadest possible realization of the declared Congressional purpose, will doubtless induce the Wage and Hour Division to continue to urge a liberal interpretation of the phrase "engaged in processes necessary to production"; yet it appears that practical difficulties may induce the administration to concede certain relaxations of the broad rule originally urged; and it is not at all unlikely that court decisions may further restrict the effect of the phrase, to the end that eventually coverage may be limited to those employees who are actually on the production line, or are engaged in the performance of a job which must be done to keep the production line going.

\section{B. Goods for Commerce}

Employees engaged in processes necessary to the production of goods are entitled to the benefits of the Fair Labor Standards Act only if the goods produced are "goods for commerce." The extent to which this phrase will eventually be held to limit the coverage of the Act depends largely on questions of constitutional law beyond the scope of this article, and no more will be here undertaken than to suggest certain points at which constitutional limitations may reduce the effectiveness of the Act. ${ }^{44}$

I. Where Employer Sells Part of His Goods on An Interstate Market.

Current trends toward decentralization of industry make this classification probably the most inclusive. ${ }^{45}$ By making the touchstone the nature of the work of the individual employee, Congress has extended the benefits of the Act to every employee whose work is connected with the production of some goods that move on an interstate market; regardless of the percentage of the goods manufactured in his employer's establishment that are so marketed. If the constitutionality of this test is established, the coverage will be much broader than under most federal laws enacted under the aegis of the commerce clause. Prior laws, referring to the direct effect of the employer's business as a whole on the flow of interstate commerce, excluded many plants whose interstate sales, constituting but a small percentage of the total output, were so small as to be insignificant, when viewing the nature of the employer's business. ${ }^{46}$ By looking instead to the nature of the employee's work, the field in which the Act operates is vastly broadened. While the conclusion seems inescapable that the Act makes no distinction as to the percentage of the employer's products (or of the goods on which the employee works) that move in interstate

not touch articles, inspectors who do, superintendents, foremen, watchmen, power house operators, first aid attendants, tool crib men, truck drivers, equipment maintenance men, die try-out men, stcamfitters, electricians, janitors.

"Constitutional issues are dealt with in the opinions of Messrs. Stern and Smethurst at pp. 433 and 444 infra.

${ }^{15}$ While no completely satisfactory statistics are available, it appears that even most parts manufacturers, who sell products that are later to become incorporated as a part of another article, number among their customers a substantial proportion who take shipments across state lincs. It seems that most companies whose sales are exclusively intrastate supply but a single customer, who is so closely identified with the selling company that the two can be treated as one. $C \dot{j}$. National Labor Relations Board v. Jones \& Laughlin Steel Corp., 30r U. S. I (1937).

10 This problem is more fully discussed, with reference to constitutional questions in my article, supra note 4 , at $35-45$. 
commerce, the Administrator has buttressed his opinion to this effect by relying on the legislative history of the Act, the President's message advocating the passage of wage and hour legislation, the finding and declaration of policy in Section 2(a) (I)

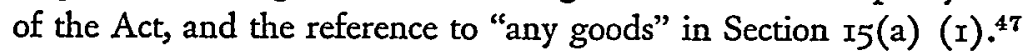

Of course, sometimes the destination of goods is not known until they have been sold. While administrative convenience would be best subserved by a rule that the residence of the ultimate consignee determined whether or not the goods were produced for commerce, yet this would produce unfair retroactive results-as in a case where an employer, at the time the goods were produced, expected to sell the entire output to a customer located within the same state, but later found it necessary to dispose of a part of his stock out of the state. Recognizing this situation, the Administrator has ruled that whether or not the goods are intended for commerce depends on whether the manufacturer at the time of production believes, or hopes, or has reason to believe that the goods in production will move in interstate commerce. ${ }^{48}$ The unexpected occurrence of some subsequent event is not retroactively significant. ${ }^{49}$

2. Where Employer Sells All His Goods within the State to One Who Subsequently Effects Interstate Distribution.

Where the stoppage does not affect the character of the goods, it seems fairly predictable that the Act will be held to be validly applicable to the production of goods sold within the state of manufacture to a vendee who effects interstate distribution thereof, whether the stoppage of the goods in the hands of the first vendee be merely for reshipment or for storage. ${ }^{50}$ Clear it is that the Administrator makes no distinctions based upon the length or character of the stoppage in the hands of the intermediate consignee; he states bluntly, "It is immaterial that the producer passes title to the purchaser within the State of production."51

Where, however, the goods produced by the first employer are subjected to further processing or manufacturing by the purchaser within the same State, constitutional questions of grave import are at once encountered. ${ }^{52}$ The Administrator urges that

'7 Interpr. Bull. No. 5, Dec. 2, 1938, I WAGE \& Hour REF. MAN. (1939) 74, 75.

${ }^{48} \mathrm{Id}$.

10 ". . . if a shirt manufacturer produces shirts to fill the order of a local retail store in the expectation that the shirts will be sold for consumption within the State of production, the manufacturer will not become retroactively subject to the Act in respect to those goods, because the retailer subsequently goes bankrupt and its whole stock of merchandise, including the shirts, is bought up by an out-of-State merchant and removed to another State. On the other hand, if the shirt manufacturer produced the goods to fill an out-of-State order, the rights of the employees under Sections 6 and 7 of the Act are not affected by the subsequent fact that a fire destroys the finished shirts before they are shipped out of the State." Id.

${ }^{50}$ Cases are discussed in (1939) 52 Harv. L. Rev. 646, at 657.

${ }^{61}$ Interpr. Bull. No. 5, Dec. 2, 1938. It is interesting to note that in determining the applicability of state sales tax laws, the situs of the transfer of title is often made the controlling factor. See Lockhart, The Sales Tax in Interstate Commerce (1939)' 52 HARv. L. Rev. 6r7.

62 Under the doctrine of the Jones \& Laughlin decision it seems that further processing by a subsidiary of the original manufacturer does not create constitutional barriers. But in N. L. R. B. v. Idaho-Maryland Mines Co., 98 F. (2d) 129 (C. C. A. 9th, 1938), it was held that the Wagner Act did not apply to a strike at a coal mine where it appeared that all the gold there mined was refined by an independent purchaser before shipment out of the State. This appears to be the only case involving an independent intermediary under the National Labor Relations Act. Quaere, whether the persuasive power of this case is weakened by the decision in Mulford v. Smith, 59 Sup. Ct. 648 (1939). 
the Act applies not only where the first product becomes an ingredient or an integral part of the subsequent product, but even where the first product is merely a container or label.53 Whether the production of a label becomes "the making of goods for commerce" simply because the purchaser of the label subsequently affixes it to goods manufactured by him and sold in interstate commerce, would seem doubtful, however, even as a matter purely of statutory construction and independent of constitutional questions.

\section{Definition of "Goods."}

The problem last discussed lends significance to the problem of interpreting the statutory definition of goods as "wares, products, commodities, merchandise, or articles or subjects of commerce of any character, or any part or ingredient thereof. ..."54 It seems clear to the Administrator that the term includes "publications, pamphlets, or any other written materials." ${ }^{55}$ It would seem that a lawyer's brief, or an insurance policy, might be goods, if reports of research agencies are held to be, as suggested by the Administrator in the Interpretative Bulletin last cited. The ever-perplexing problem of the distinction between sales and service contracts may thus arise in a new setting. Coverage of the Act may be extended to non-manufacturing enterprises. $^{56}$

4. Segregation of Employee's Work.

While the Act creates a presumption of an employee's engagement in the production of goods upon proof of his employment in a plant where goods shipped in commerce were produced, ${ }^{57}$ the Administrator has voiced the opinion ${ }^{58}$ that the Act does not require an employee who spends only a part of his time in the production of goods for commerce to be accorded the benefits of the statute during all the time that he works. If he works one week on goods destined for a local market, and the next week on goods for commerce, his employment is subject to the provisions of the Act only during the second week. But the Administrator does not permit segregation between interstate and intrastate work during a single week, for the reason that otherwise it would be easy to defeat the objectives of the Act by employing workers for 44 hours in the production of goods for commerce, and employing them for additional hours during the same work-week, in the production of goods to be sold locally, without increasing their rate of pay for the overtime hours.

\section{EXEMPTIONS}

While the clauses of the Act above discussed paved the way for administrative freedom of action by defining in flexible and broadly inclusive terms what groups

${ }^{83}$ Interpr. Bull. No. 5, Dec. 2, 1938.

54 $\$ 3$ (i), adding: "but [the term] does not include goods after their delivery into the actual physical possession of the ultimate consumer thereof other than a producer, manufacturer, or processor thercof."

¿t Interpr. Bull. No. 5, Dec. 2, 1938.

${ }^{86}$ Interpr. Bull. No. 6, Dec. 7, I938, I WAGE \& Hour Ref. MAN. (1939) 76. Some of the problems arising in connection with the exemption of service industries are discussed infra p. 349 .

$5 \mathrm{r}_{5}(\mathrm{~b})$.

${ }^{58}$ Questions and Answers, No. 9, Feb. 27, 1939, which warns that the Administrator has no power to make definite rulings as to the coverage of the Act and that no opinion expressed by him will protect the employer in the event of an employee suit. 
of workers were covered by the Act, a similar result is achieved through an opposite technique in the exemption sections of the law. Here (except for some specific exemptions established in favor of certain well defined classes of employees), the Act in large measure delegates to the Administrator the power to decide what workers should be exempted. This result is achieved through a simple device. Section I3 of the Act declares that there shall be exempted from the provisions of the Act all employees of certain classifications, as such classifications are defined by the Administrator.

Examination of the exemption sections is therefore of interest from two aspects: first, because of the possibility (in view of the administrative interpretations above discussed) that substantially all employees of companies doing an interstate business are under the Act, unless they fall within one of the exempted classes; secondly, because the numerous regulations, interpretative bulletins, and letters published by the Wage and Hours Division of the Department of Labor afford a timely example of the administrative implementation of a somewhat barren statutory framework.

The exempting clauses of the Act may be divided into three classes: those granting exemptions only from the wage provisions of the Act; those granting exemptions only from the hours provisions; and those granting exemptions from both wage and hours provisions.

\section{A. Exemptions from Wage Provisions}

In the case of learners, apprentices, messengers, and handicapped workers, the Act provides an exemption only from the wage provisions. The applicable exempting clauses $^{50}$ are not self-operative; but merely authorize the Administrator, by regulations and orders, to provide lower wages for these classes of employees, if he finds such exemptions necessary to prevent curtailment of opportunities for employment. The exemptions become operative only upon the issuance of special certificates by the Administrator. Detailed and explicit regulations have been issued, which make the procurement of these certificates so difficult that during the first several months following the effective date of the Act, not a single certificate for the employment of learners or apprentices had been issued, although many applications had been filed.

Messengers and Learners. In the case of messengers and learners, the regulations $^{60}$ add significantly to the statutory background by providing that all applications will be considered and acted upon on the basis of the needs of the employees and employers in any industry as a whole, rather than upon the basis of the needs

\footnotetext{
${ }^{60}$ \$ 4: "The Administrator, to the extent necessary in order to prevent curtailment of opportunities for employment, shall by regulations or by orders provide for ( $I$ ) the employment of learners, of apprentices, and of messengers employed exclusively in delivering letters and messages, under special certificates issued pursuant to regulations of the Administrator, at such wages lower than the minimum wage applicable under section 6 and subject to such limitations as to time, number, proportion, and length of service as the Administrator shall prescribe, and (2) the employment of individuals whose earning capacity is impaired by age or physical or mental deficiency or injury, under special certificates issued by the Administrator, at such wages lower than the minimum wage applicable under section 6 and for such periods as shall be fixed in such certificates."

${ }^{00} 29$ Code Fed. Reg., c. 5, Pts. 522, 523; I Wage \& Hour Ref. Man. (I939) 83, 84.
} 
of individual employees or employers in the industry. ${ }^{61}$ The regulations further provide that on the filing of an application, a hearing will be had thereon, at which the Administrator or his representative will decide, on the basis of testimony offered by the applicant and that adduced by expert witnesses called by the Administrator to advise him as to the need of issuing a certificate to prevent curtailment of employment opportunities, whether or not an exemption shall be granted. While it might be feared that a judge who selects experts to advise him as to the facts of a case might be disposed to rely too heavily on the opinions they give, the practical advisability of such a procedure, to prevent the hearing on the application from being one-sided and in effect ex parte, is quite apparent. It should be noted, however, that there is no provision for appeal as of right to the Administrator from the decisions of the deputy who conducts the hearing. The regulations permit an aggrieved applicant to petition the Administrator, requesting him to review the original determination; but the Administrator may refuse to grant such petition for any reason he deems sufficient, as if he is of the opinion that the findings of ultimate fact made by the deputy support the ruling, and are supported by the evidence adduced.

Indicative of the administrative attitude are the rulings made on the application of a group of telegraph companies for messengers' certificates, and on the application of pecan shellers for learners' certificates. In the former case, it was indicated that a threatened discharge of employees of a particular company or companies will not establish that a certificate is necessary in order to prevent curtailment of opportunities for employment, unless the applicant shows that the employees involved would be unable to secure other employment elsewhere. ${ }^{62}$ In the latter case, exemptions were denied because of a finding that the employers could employ experienced pecan shellers in sufficient numbers to meet labor requirements. ${ }^{63}$ The implications of such rulings, placing as they do upon the applicant a burden of proof which as a practical matter is probably impossible to sustain, are portentous. They will probably discourage employers from seeking exemptions, and thus, in actual practice, will extend the effective coverage of the Act. Perhaps these considerations played some imponderable part in the making of the administrative decisions.

Apprentices. A somewhat different approach is employed with reference to the issuance of apprentices' certificates, which are issued (providing the Administrator finds an apprenticeship is necessary in the trade involved) upon the filing of a joint application, signed by both employer and employee, together with an authenticated copy of a written apprenticeship agreement which has been approved by the State Apprenticeship Council, and which provides for not less than 4,000 hours of reasonably continuous employment, and at least I44 hours per year of related supplemental instruction. ${ }^{64}$

\footnotetext{
${ }^{61}$ Within the last few days, however, it has been announced that henceforth granting of exemption! for learners will be on a plant basis. (1939) 2 WAGE \& HouR REp. 26x. New regulations concerning learners are being promulgated currently.

${ }^{62}$ (1938) 3 LAb. Rel. Rep. $377 . \quad{ }^{03}$ I Wage \& Hour Rer. MaN. (1939) 84.

o4 29 Code Fed. Reg., c. 5, Pt. 52I; I Wage \& Hour Ref. Man. (r939) 8 I.
} 
Handicapped Workers. Similarly, in case of handicapped workers, the regulations provide that upon receipt of a joint application setting forth in detail the nature of the handicap and the necessity of authorization of employment at sub-minimum wages to prevent curtailment of the employee's opportunities for employment, the Administrator or his representative may award a certificate or make a further investigation to determine what action should be taken. It is further provided that, except on the basis of such investigation, no certificate will be issued authorizing employment of handicapped workers at less than $75 \%$ of the statutory minimum wage. ${ }^{65}$

Messengers, learners, apprentices, and handicapped workers must be paid at one and a half times their regular hourly rate of pay for overtime work performed by them; the exemption granted them applies only to authorization of a sub-standard hourly rate.

\section{B. Exemptions from Hours Provisions}

Another group of exemptions grant immunity only from the hours provisions of the statute. In case of seasonal workers, some agricultural processors, employees whose hours of service are controlled by the Interstate Commerce Commission, employees under approved annual wage agreements, and employees hired under approved collective bargaining agreements containing certain provisions relative to hours worked, the exemptions afforded under the law authorize employment in excess of 44 hours per week without payment of one and a half the regular hourly rate of pay for such overtime employment.

Seasonal Industries. The exemption for workers in seasonal industries is limited in two ways: first, it is applicable only to workers in an industry which is found by the Administrator to be of a seasonal nature (thus, under the plain language of the statute, a finding by the Administrator is a condition precedent to the effectiveness of the exemption); second, as to such workers, the exemption is applicable only for periods not to exceed in the aggregate 14 weeks in any calendar year, and even during the $\mathrm{r}_{4}$ weeks they must be paid time and a half for employment in excess of $\mathrm{I} 2$ hours in any work-day, or for employment in excess of 56 hours in any work-week. ${ }^{66}$

The regulations ${ }^{67}$ define a seasonal industry in terms which exclude any enterprise that is not compelled by conditions of nature to cease production except during periodically recurrent intervals, ${ }^{68}$ and thus seem to exclude all manufacturing industries, or substantially all. The Division has further indicated, through its general counsel, that no single plant will be exempted even though it meets the definition of

ot 29 Code Fed. Reg., c. 5, Pt. 524; I Wage \& Hour Reg. MaN. (I939) 90.

$00 \$ 7(\mathrm{~b})$.

o7 29 Code Fed. Reg., c. 5, Pt. 526; I Wage \& Hour Ref. Man. (I939) 54.

${ }^{08}$ The regulations provide that the exemption is applicable to "an industry which both (a) engages in the handling, extracting, or processing of materials during a season or seasons occurring in a regularly, annually recurring part or parts of the year; and (b) ceases production, apart from such work as maintenance, repair, clerical and sales work, in the remainder of the year because of the fact that, owing to climate or other natural conditions, the materials handled, extracted, or processed, in the form in which such materials are handled, cxtracted, or processed, are not available in the remainder of the year." I WAGE \& Hour REF. MAN. (1939) 55. 
"seasonal" as laid down by the Administrator. The exemption is granted only on the basis of trades and industries that are seasonal..$^{69}$

Further restrictions on this exemption were indicated by the ruling on an application of certain lumber manufacturers. Despite a showing that the operations of cutting, hauling, and pulpwood peeling were carried on under conditions which met the administrative definition of seasonal, it was held that these enterprises did not constitute separate industries, but were (regardless of unit ownership) merely subdivisions of the lumbering industry, which, taken as a whole, could operate throughout the year. Therefore, and with the additional observation that enough employees were available for work to permit operation of the industry even though the exemption were not granted, the application was denied. ${ }^{70}$

Collective Bargaining Agreements. The provisions of Sections 7 (b) I and 7 (b) 2 of the Act, granting limited exemptions as to workers employed under certain types of collective bargaining agreements, or annual wage agreements, can be discussed together. An employer who hires workers on an annual basis, or on the basis of a contract relating to a 26-week period, pursuant to collective bargaining agreements made with employee representatives certified as bona fide by the National Labor Relations Board, may obtain the right to average overtime over a period of time. If such agreements provide that no employee shall be employed more than 2,000 hours in 52 consecutive weeks, or 1,000 hours in 26 consecutive weeks, an employee may be required to work up to I2 hours in one day or 56 hours in one week, without payment of extra compensation for the overtime hours. These provisions may lead to wider use of guaranteed annual wage contracts, since the Administrator has ruled that the statutory exemption applicable to employees hired on an annual basis may be availed of only if the employer guarantees either a fixed annual wage or annual employment. ${ }^{71}$ On the other hand, where the worker is employed pursuant to an agreement which provides that no employee shall be employed more than 1,000 hours in any priod of 26 consecutive weeks, the employer need not guarantee continuous employment or a fixed wage; and this type of agreement may be more attractive to employers. ${ }^{72}$ The National Labor Relations Board will certify the employee representative group as bona fide if any other local of the same union has already been certified as a collective bargaining agent under the National Labor Relations Act, unless cause to the contrary is shown ${ }^{73}$ Adoption of either of these devices will

${ }^{60}$ Id. at 57.

${ }^{70}$ The r2-page typewritten opinion in which this ruling was laid down proceeds with the closclyreasoned formality of a judicial decision. The Wage and Hour Division appears to break cleanly away from the often-criticized tendency of administrative tribunals to keep secret the reasons for their orders.

Since the writing of the text, the Administrator on reviewing this determination, reversed it to the extent of holding that the pulp wood sap peeling branch of the industry, the ice and snow road hauling branch of the industry, and the spring freshet driving branch of the industry are of a seasonal naturc.

${ }^{71}$ Interpr. Bull. No. 8, Feb. 20, I939, I WAGE \& Hour REF. MAN. (1939) 205.

${ }^{72}$ Id.

${ }^{73}$ The National Labor Relations Board has stated that an employee organization will be ccrtificd as bona fide, for purposes of the Fair Labor Standards Act, under the following circumstances: $(I)$ where the labor organization has been certified by the Board as a collective bargaining representative of the employees pursuant to $\$ 9$ of the National Labor Relations Act; or (2) where the applicant is a local 
necessitate careful watching of employees' time cards, because the Administrator has ruled that if the employer works such employees in excess of $I, 000$ or 2,000 hours, during the period stated, he will become liable for overtime compensation (at extra rates) to such employees for all hours which they worked in excess of 44 hours in any work-week during the period. ${ }^{74}$

Agricultural Processors. The hours exemption granted certain agricultural processors $^{75}$ raises difficult administrative problems, which are still far from solution, in connection with the administrative duty of defining "area of production." wise, the statutory provisions appear to provide little source of interpretative difficulty.

Hours Fixed by Interstate Commerce Commission. The final exemption from the requirement of paying increased compensation for overtime work applies ( $\mathrm{I}$ ) to any employee with respect to whom the Interstate Commerce Commission has power to establish qualifications and maximum hours of service pursuant to the provisions of Section 204 of the Motor Carrier Act; and (2) to any employee of an employer subject to the provisions of Part I of the Interstate Commerce Act. ${ }^{77}$

\section{Exemptions from Wage and Hours Provisions}

The most important exemptive provisions of the Act are those granting complete exemption to the following twelve classes of workers: (a) executive and administrative employees, as the class is defined and limited by the Administrator; (b) professional employees, as the class is defined and limited by the Administrator; (c) outside salesmen, as the class is defined and limited by the Administrator; (d) employees engaged in a local retailing capacity, as the class is defined and limited by the Administrator; (e) employees of retail and service establishments, the greater part of whose selling or servicing is in intrastate commerce; $(f)$ certain aviators; $(g)$ seamen; (h) fishermen; (i) employees engaged in agriculture; (j) employees engaged, within the area of production (as defined by the Administrator) in preparing for

of an international or parent organization which has been certified by the Board as a collective bargaining representative of the employees pursuant to $\$ 9$ of the National Labor Relations Act; or (3) where any local of an international or parent organization with which the applicant is affiliated has been so certified as a collective bargaining representative pursuant to the National Labor Relations Act, such certification shall be sufficient basis for certification of bona fides under the Fair Labor Standards Act, for any local of the same international. I WAGE \& HouR REF. MAN. (1939) 57.

${ }^{24}$ Interpr. Bull. No. 8, Feb. 20, 1939, I WAGE \& Hour REF. MAN. (1939) 205.

${ }^{75} \S_{7}(\mathrm{c})$ of the Act, providing: "In the case of an employer engaged in the first processing of milk, whey, skimmed milk, or cream into dairy products, or in the ginning and compressing of cotton, or in the processing of cottonseed, or in the processing of sugar beets, sugar beet molasses, sugarcane, or maple sap, into sugar (but not refined sugar) or into syrup, the provisions of subsection (a) shall not apply to his employees in any place of employment where he is so engaged; and in the case of an employer engaged in the first processing of, or in canning or packing, perishable or seasonal fresh fruits or vegetables, or in the first processing, within the area of production (as defined by the Administrator), of any agricultural or horticultural commodity during seasonal operations, or in handling, slaughtering, or dressing poultry or livestock, the provisions of subsection (a), during a period or periods of not more than fourteen workweeks in the aggregate in any calendar year, shall not apply to his employees in any place of employment where he is so engaged."

${ }^{70}$ The regulations on this point are undergoing current study by the Administrator; the treatment of the problem appears to be in a state of flux. See various regulations, I WAGE \& Hour ReF. MaN. (I939) I $1,79,8 \mathrm{x}, \mathrm{x} 93$.

${ }^{77} \$ 13(b)$. 
market agricultural or horticultural commodities; ( $k$ ) employees of certain country newspapers; (1) employees of street railways and motor bus carriers.

Executive and Administrative Workers. Regulations under the Walsh-Healey Act afforded some grounds for anticipating that all employees might be deemed executive or administrative workers whose chief function was to give, or to supervise the carrying out of, general orders. Such expectations failed completely of realization. The Administrator has ruled that under the Fair Labor Standards Act, only those em. ployees fall within this class whose jobs possess all of the following six characteristics: (I) management of establishment or customarily recognized department thereof; (2) direction of work of other employees; (3) authority to hire and fire, or to make recommendations carrying particular weight in these matters; (4) exercise of discretionary powers; (5) compensation of at least $\$ 30$ a week (exclusive of board, lodging, or other facilities); (6) performance of no substantial amount of work of the same nature as that performed by non-exempt employees. ${ }^{78}$ The last requirement has proved particularly troublesome to employers, since many employees who have traditionally been deemed minor executives do a certain amount of work somewhat similar in nature to that performed by their assistants-a corporation treasurer, for example, may set up work sheets as models for bookkeepers to follow. For adminis. trative convenience, perhaps, and perhaps in compliance with a clearly indicated administrative policy of going half-way in meeting and satisfying reasonable complaints of employer groups, the Division (according to press reports) may change the regulations on this point so as to define as "executive or administrative" any salaried employee receiving more than $\$ 35^{\circ}$ per month. Such action may be dictated by Congress; several amendments are pending. ${ }^{79}$

Professional Employees. Possibilities that a color-matcher employed in the printing ink industry might be a professional employee, and that conceivably a doctor or attorney might not be, loom as the result of the somewhat puzzling definition of the term "professional employee" promulgated by the Administrator pursuant to statutory authority. ${ }^{80}$ It would seem that perhaps a physician employed solely to examine life insurance applicants, or an attorney employed to check transfers of

${ }^{78}$ I WAGE \& Hour REF. MAN. (1939) 78.

${ }^{79}$ It would seem that in the case of employees being paid such a salary for the performanco of nonmanual work, the employees are paid for their ability to handle situations as they arise. Many such workers have a comparatively light load for several weeks, and then face a situation which requires considerable overtime work for several days, in order to keep things flowing smoothly; and it is fair to assume that their salary is fixed in part at least in the expectation of such a work schedule.

${ }^{80}$ The regulations provide that a professional employee is one: "who is (a) customarily and regularly engaged in work (i) predominantly intellectual and varied in character as opposed to routine mental, manual, mechanical or physical work, and (ii) requiring the consistent exercise of discretion and judgment both as to the manner and time of performance, as opposed to work subject to active direction and supervision, and (iii) of such character that the output produced or the result accomplished cannot be standardized in relation to a given period of time, and (iv) based upon educational training in a specially organized body of knowledge as distinguished from a general academic education and from an apprenticeship and from training in the performance of routine mental, manual, mechanical, or physical processes in accordance with a previously indicated or standardized formula, plan or procedure; and (b) who does no substantial amount of work of the same nature as that performed by nonexempt employees of the employer." I WAGE \& HoUR REF. MAN. (r939) r94. 
property in a register of deeds' office, might not fall within the requirements of the definition, providing in part that professional work must be varied in character, requiring judgment as to the time of performance, and of such a nature that the output produced cannot be standardized in relation to a given period of time. On the other hand, the Administrator recently advised that the color-matcher might be a professional employee. ${ }^{81}$

Outside Salesmen. Vendors of food-stuffs, who make recurrent routine deliveries (whether or not prior orders are placed by purchasers) or collections, are specifically excluded from this exempt classification by the administrative definition, which otherwise requires but little comment, providing as it does that outside salesmen are those customarily and regularly engaged in making sales away from the employer's place of business, who do no substantial amount of work of the same nature as that performed by non-exempt employees of the employer. ${ }^{82}$

Those Engaged in Local Retailing Capacity; Employees of Retail and Service Establishments the Greater Part of Whose Selling or Servicing is in Intrastate Commerce. While these sections, taken together, cover closely related fields, yet Congress empowered the Administrator to define only the meaning of the first clause, "employees engaged in a local retailing capacity." establishment the greater part of whose selling or servicing is in intrastate commerce" 84 is left to the courts for definition. The result may be a conflict. The Administrator has defined the first class to include workers customarily and regularly engaged in making retail sales the greater part of which are in intrastate commerce, or performing work immediately incidental thereto, such as the wrapping or delivery of packages, who do no substantial amount of work of the same nature as that performed by nonexempt employees of the employer. ${ }^{85}$ The Administrator has made his definition more specific through an Interpretative Bulletin suggesting a construction of the words "retail" and "service" establishments. While his interpretation of the word "retail" is apparently binding as to employees engaged in a local retailing capacity, it may be that the courts will interpret the same word otherwise in determining whether an enterprise is a retail establishment. In an Interpretative Bulletin ${ }^{86}$ relating to the meaning of the phrase "retail and service establishments," it is suggested that retail establishments generally sell consumers goods in small quantities, and that a company selling coal in large quantities to a manufacturer would not be a retail establishment, while a company selling a few tons of coal to a householder would be. It is further suggested in the Interpretative Bulletin that since retail establishments and service establishments are referred to in the same sentence of the Act, the definition of service establishments should be limited to concerns of a sort generally associated with retail stores, such as restaurants and barber shops; and that such enterprises as advertising agencies, banks, stock brokers, printers, investment

\footnotetext{
${ }^{81}$ Questions and Answers No. 9, Feb. 27, 1939.

${ }^{83}$ I WAGE \& Hour REF. MAN. (I939) 79.

${ }^{81}$ Ibid.

${ }^{85}$ I WAGE \& HoUR REF. MAN. 79.

${ }^{88}$ Interpr. Bull. No. 6, Dec. 7, 1938; I Wage \& Hour REF. MAN. (1939) 76.
} 
counsel, legal firms, accounting firms, and warehouse companies are not service establishments. Apparently for purposes of administrative convenience, it is suggested that in case of an organization engaging both in wholesale and retail selling, there must be some physical separation between the wholesale and retail branches of the business if the exemption is to apply. In determining whether or not the greater part of the selling or servicing is in intrastate commerce, the Administrator suggests that there should be considered the number of sales and gross income over a reasonable period of time, typically three years.

Other Exempted Classes. Little comment is required with reference to the other exempted classes of employees. The statutory definitions are comparatively specific, and there is less delegation to the Administrator of power to write the law by determining the limits of the classes involved. The exemption of seamen has been interpreted ${ }^{87}$ as including those performing services rendered primarily as an aid in the operation of a vessel as a means of transportation. The exemption for workers employed in agriculture is pointed by the definition of farming (given elsewhere in the Act) ${ }^{88}$ as including any practices performed on a farm in conjunction with farming operations. Apparently, maintenance workers and watchmen employed on farms are exempted, ${ }^{89}$ although workers performing similar jobs in factories (as above pointed out) are deemed by the Administrator not to be excluded, but to be within the Act. The exemptions of individuals employed within the area of production engaged in handling, packing, storing, ginning, compressing, pasteurizing, drying, preparing in their raw or natural state, or canning of agricultural or horticultural commodities for market, or in the making of cheese or butter or other dairy products, ${ }^{90}$ creates the extremely difficult administrative problem, hereinabove alluded to, of devising a practicable definition of "area of production." Other exemptions exclude from the Act any employee of a carrier by air subject to the provisions of Title II of the Railway Labor Act, employees engaged in various specifically defined branches of the fishing industry, employees of a street, suburban, or interurban electric railway, or local trolley or motor bus carrier; and employees engaged in connection with the publication of a weekly or semi-weekly newspaper with a circulation of less than 3,00o, the major part of which circulation is within the county where the newspaper is printed and published. ${ }^{11}$

\section{Determination of Hours Worked and Hourly Rate of Pay}

Practical problems of considerable difficulty arise in connection with the determination of the number of hours worked and with the computation of the hourly rate of pay. The Act was written with primary reference to hourly-wage employees; but as it has been administratively interpreted it applies to many office workers who have customarily been employed on a weekly or monthly salary which has been paid without regard to the number of hours actually worked.

\footnotetext{
${ }^{87}$ Interpr. Bull. No. II, April 29, 1939.

${ }^{80}$ Questions and Answers, I WAGE \& Hour Rer. MAN. (r939) 96.

${ }^{80} \$ I_{3}(\mathrm{a})$ ro. QI $\$ 13$.
} 
Many employers who hire employees on a weekly wage and require them occasionally to work more than 44 hours during a single week wish to adopt the most practical and cheapest procedure available to assure themselves that they are complying with the Act and with all the regulations issued thereunder. ${ }^{92}$

Such an employer often faces the problem of revising his pay-rolls so as to achieve unquestionable compliance with the Act without prohibitive increases in his wage costs. Suppose he hires several employees who are paid $\$ 40$ for a $5^{0}$-hour week. Each such employee gets the equivalent of 80 cents an hour; his weekly remuneration is far above the minimum contemplated by the Act (which will eventually be 40 cents an hour for the first 40 hours and 60 cents an hour for additional hours of work in any week). It would seem that the primary purpose of the Act could be fulfilled by continuing such an employee on the payroll at his weekly wage of $\$ 40 .^{93}$ This was the interpretation which apparently was first placed upon the Act by the Administration -in October, 1938, Associated Press articles quoted authorities as announcing unofficially that a worker employed on a flat weekly salary might be worked more than 44 hours a week without increased pay, provided his total earnings were not below the minimum requirements of the law.94 More recently, however, it has been offcially ruled that this cannot be done. The regulations require time-and-a-half for overtime, regardless of the rate of pay or basis on which wages are computed. An employee receiving $\$ 40$ for a 50 hour week would be deemed to be paid at the rate of 80 cents an hour, and the regulations require that his weekly wage be increased to $\$ 42.40(\$ .80 \times 44$ plus $\$ \mathrm{r} .20 \times 6) .^{95}$

It would seem that the most practical expedient for the employer is to change such

Ds Indicative either of a general acceptance of the purposes of the Wage and Hour Law, or possibly of a resignation to federal control of business practices, is the fact that employers with whom the writer has had contact have expressed a desire to comply in all respects with the statute; and, even though grave doubts existed as to applicability of provisions of the Act to certain of their employees, have treated all of their employees as being subject thereto.

${ }^{03}$ This, of course, raises the broad question as to what the real purpose of the Act is. While the Congressional declaration of policy in Section 2 declares the policy of the Act to be that of correcting and eliminating labor conditions detrimental to the maintenance of minimum standards of living necessary for health, efficiency, and general well-being of workers, many believe that an equally fundamental purpose of the Act is to induce work-sharing. While the latter may be a practical concomitant of the Act, it would seem that the officially announced purpose may properly be regarded as the true intent of the legislation.

${ }^{04}$ Much interchange of opinion and comment has been indulged in this connection. On Sept. 29, 1938, the Administrator is reported to have stated, in reply to a question asked at the conclusion of a speech given by him in Birmingham, Ala., that a minimum wage law is the floor of the very lowest wage to be pegged, and that the law did not contemplate establishment of several minimum wages within a single plant. Associated Press releases of Oct. 20, 1938, stated in part: "This is the unofficial advice which some wage-hour authorities have given in response to inquiries: .. . A worker now employed on a flat weekly salary might be worked overtime without increased total pay by regarding his hourly rate as being at a lower figure." John. C. Gall, General Counsel for the National Association of Manufacturers, issued an opinion which in general reached a somewhat similar result. I WAGE \& HouR REF. MAN. (I939) 59, 60. The Administrator replied, stating that the Wage and Hour Division did not agree with Mr. Gall's opinion. Id. at 60,61. The subject is discussed in an editorial in the New York Times of Tuesday, Oct. $25,1938$.

${ }^{O C}$ Similarly, the average hourly rate of a piece-worker is computed by dividing his piece-rate earnings for a week by the number of hours worked during the week, and then; paying a bonus for those hours in excess of 44. 29 CODE Fed. Reg., c. 5, Pt. 516; I WAGE \& HouR Ref. MaN. (1939) I05; Interpr. Bull. No. 4, Oct. 2I, I938, I WAGE \& Hour REF. MAN. (1939) 54. 
employee's basis of pay to 76 cents an hour. Then, paying time-and-a-half for overtime, his total weekly earnings (if he worked 50 hours) would be $\$ 40.28$ ( $\$ .76 \times 44$ plus $\$$ r.I $4 \times 6$ ) or approximately the same as they had been under the original flat weekly rate.

While counsel for the Wage and Hours Division have warned that this practice is not authorized by the Act, ${ }^{06}$ the writer submits that it is not prohibited by the Act; and, further, that it complies both with the letter and with the spirit of the law. True, Section $\mathrm{I} 8$ provides in part that, "No provision of this Act shall justify any employer in reducing a wage paid by him which is in excess of the applicable minimum wage under this Act"; but the wishful language of this section (which was at one time termed by the Administrator to be nothing more than a "pious hope" on the part of Congress) by its own terms applies only to reductions of wages. It does not refer to changing the method by which wages are computed. The procedure suggested does not result in a reduction of wages-the employee receives the same weekly wage as before, if he does the same amount of work. Indeed, in the example given, the employee's wages are increased 28 cents a week. Further, the essential legislative purpose-assuring a living wage for a short week's work-is not defeated. If the employee referred to wished to work only 44 hours a week, he would still receive $\$ 33.44$.

\section{Conclusion}

Perhaps the chief practical defect in the coverage provisions of the Act is that because of constitutional limitations the law can have no application to thousands of employees (in retail stores, barber shops, restaurants, hotels, other retail and service establishments, and small factories operating exclusively intra-state) who probably constitute the largest class of underpaid workers. ${ }^{07}$ There is a real need for further state laws, requiring payment of a fair day's wages for a fair day's work, and restricting or prohibiting employment in excess of the maximum number of hours consistent with health and efficiency. ${ }^{98}$

${ }^{\circ 0}$ See excerpts from speeches, I WAGE \& Hour REF. MAN. (1939) 62, 63; cf. Interpr. Bull. No. 4, Oct. 21, I938, I WAGE \& HouR REF. MAN. (1939) 54 .

${ }^{87}$ This situation is discussed in some detail in the writer's article cited, supra note 4 , at 54 et. seq.

${ }^{08}$ These ends can of course be achieved by laws that do not incorporate the work-sharing philosophy inherent in the Federal Act. Prohibition of employment more than an average of nine hours a day or 54 hours a week in certain industries, and a minimum rate of pay of 25 cents to 35 cents an hour, without retention of the device of requiring extra pay for hours worked in excess of a minimum devised otherwise than on health-conservation principles, would accomplish the declared purpose of Congress. 